\title{
STUDY OF ANTIMICROBIAL PROTEIN FROM THE HEMOLYMPH OF FRESHWATER CRAB OZIOTELPHUSA SENEX SENEX AND ITS EFFICACY AGAINST THE HUMAN PATHOGENS
}

\author{
SUMALATHA $\mathrm{D}^{1 *}$, NITHYA TG ${ }^{2}$, JAYANTHI J ${ }^{3}$, RAGUNATHAN MG ${ }^{4}$ \\ ${ }^{1}$ Department of Biotechnology, Valliammal College for Women, Chennai, Tamil Nadu, India. ${ }^{2}$ Department of Biotechnology, Faculty of \\ Science and Humanities, SRM Institute of Science and Technology, Chennai, Tamil Nadu, India. ${ }^{3}$ G.S Gill Research Institute, Guru Nanak \\ College, Chennai, Tamil Nadu, India. ${ }^{4}$ Department of Advanced Zoology and Biotechnology, Guru Nanak College, Chennai, Tamil Nadu, \\ India. Email: sumaa_dlatha@yahoo.co.in
}

Received: 22 November 2017, Revised and Accepted: 02 February 2018

\section{ABSTRACT}

Objective: The study was done to isolate the antimicrobial protein from the freshwater crab.

Methods: Antimicrobial protein was purified by sequential step of ammonium sulfate precipitation, dialysis, ion exchange chromatography, and fast protein liquid chromatography. The apparent molecular mass was determined by sodium dodecyl sulfate polyacrylamide gel electrophoresis (SDS-PAGE) and matrix-assisted laser desorption ionization-mass spectrometry (MALDI-MS/MS). Primary structure analysis was done from MASCOT search engine. The antimicrobial activity of the protein was done using well diffusion method against Gram-positive and Gram-negative bacteria.

Results: The molecular mass of antimicrobial protein was determined to be 33KDa by SDS-PAGE and MALDI-MS/MS. The antimicrobial protein contains eight peptides which were determined by MASCOT search engine. The protein exhibited antimicrobial activity both for Gram-positive and Gram-negative bacteria.

Conclusion: The results could provide information for investigating the antimicrobial protein derived from the hemolymph of the freshwater crab Oziotelphusa senex senex.

Keywords: Hemolymph, Antimicrobial protein, Purification, Gram-positive Gram-negative bacteria.

(C) 2018 The Authors. Published by Innovare Academic Sciences Pvt Ltd. This is an open access article under the CC BY license (http://creativecommons. org/licenses/by/4. 0/) DOI: http://dx.doi.org/10.22159/ajpcr.2018.v11i4.23756

\section{INTRODUCTION}

Shrimp, crab, crayfish, and lobster are well-known, commercially exploited members of Crustaceans. They are the most abundant animals inhabiting the world oceans, but there are also freshwater, terrestrial, and semi-terrestrial species [1]. Majority of the Crustaceans are aquatic found in freshwater or in marine habitats, but some are terrestrial, parasitic, and do not move. There are more than 1,300 described species of freshwater crabs, so far totally 6,700 species of crabs have been identified across all environments, out of which 1300 freshwater species have been described [2]. Crabs are the rich and excellent sources of antimicrobial proteins with multidimensional properties which are highly supported in the hemolymph study of Charybdis lucifera $[3,4]$. Bioactive peptides with health-promoting activities such as angiotensin I-converting enzyme inhibiting activity [5], anticancer effect [6], antimicrobial activity [7], immunostimulating effect [8], antidiabetic effect [9], and antioxidant effect [10] have been discovered in many plants and animals. Most of the research work has been focused on antimicrobial peptides from plants, animals, marine, and microbial sources. The literature survey revealed that freshwater crabs have historically achieved relatively less attention than marine crabs. Moreover, no detailed research of AMP so far been carried out on any Indian freshwater crabs.

Rapid growth rate, high meat content, excellent palatability and resistance to white spot virus favored the culture of crab species in aquaculture industry [11]. $O$. senex senex is a freshwater edible crab normally inhabiting in rice fields and irrigation canals throughout South India. Though their habitat is freshwater, they can also survive in seawater conditions. The outbreak of white spot disease in South India and susceptibility of prawns to virus infection resulted in search for alternate species for aquaculture. In view of resistance to white spot virus, together with a rapid growth rate, high meat content and excellent palatability, the crab species was preferred for culture in recent years. Research on 0 . senex senex has concentrated on aspects pertaining to changes in physiology during thermal and salinity adaptation [12] aspects of endocrine control of glucose, nitrogen metabolism was also studied [13]. Besides, the crab was used as a tool to monitor environmental contamination [14]. Few aspects that have been left unexamined for this crab are its potential for aquaculture, development of artificial feed, and potential fecundity of the crab. The above information is very essential to attempt culture of this species. To understand diseases affecting crabs and other ecologically and economically important crustaceans, it is necessary to have a comprehensive understanding of their immune defenses. Like other invertebrates, crustaceans do not have adaptive immune capabilities, and therefore, rely on their innate defense mechanisms [15].

Protein is imperative for normal function, growth, and maintenance of body tissues. Protein content is an important parameter for theevaluation of physiological standards of the organism [16]. The concentration of protein in the hemolymph shows the wide interspecific variation among the brachyuran crabs. Crustaceans hemolymph proteins are unique in composition, as they do not contain immunoglobulin or albumin like vertebrate proteins and the variation in protein composition is observed based on the physiological and functional state of the animal. Factors such as sex, size, stage of maturity, season, temperature, available food, molt cycle, and environment may play a key role in the variation of biochemical constituents of hemolymph proteins. [17]. Hemolymph plays a very key role in protecting the organism from various infections. In this study, we further isolate and characterize the antimicrobial potential of hemolymph from the freshwater crab 0 . senex senex. 


\section{MATERIALS AND METHODS}

\section{Collection of crabs}

Freshwater Crabs (O. senex senex) were collected from the paddy fields of Kundrathur, Kanchipuram district, Tamil Nadu, India. Healthy male and female crabs of uniform size, and free from diseases were selected for the experiments. All the crabs were subjected to single bleed collection the weight of the experimental crabs ranged between 20 and $30 \mathrm{~g}$. The crabs were acclimatized for a week in the laboratory. The species were identified by the taxonomic criteria as suggested by $\mathrm{Ng}$ [18].

\section{Collection of hemolymph}

In crab, the hemolymph was obtained by cutting each walking leg of the crab with a fine sterile scissor or using sterile 25 gauge needle. To avoid hemocyte degranulation and coagulation, hemolymph was collected along with ice-cold citrate EDTA buffer $(510 \mathrm{mM} \mathrm{Nacl,} \mathrm{0.1M}$ glucose, $30 \mathrm{mM}$ trisodium citrate, $20 \mathrm{mM}$ citric acid, $10 \mathrm{mM}$ EDTA, and $\mathrm{pH}$ 4.6) as an anticoagulant [19]. The sample was dissolved in equal volume of physiological saline (85\%, Nacl). Hemolymph was centrifuged at $10000 \mathrm{rpm}$ for $10 \mathrm{~min}$ at $4^{\circ} \mathrm{C}$ to remove the hemocytes from the hemolymph. The supernatant was collected by aspirating and stored at $4^{\circ} \mathrm{C}$ until use.

\section{Bacterial strains}

The microbial strains used to determine antimicrobial activity included three Gram-positive bacteria, namely, Staphylococcus aureus, Bacillus subtilis, Vibrio parahaemolyticus, and three Gram-negative bacteria, namely, Salmonella typhi, Pseudomonas aeruginosa, and Escherichia coli (Royal Bio research centre, Chennai). The cell number of the bacterial strains corresponding to the optical density (OD) was found out employing spread plate method. During the assay, bacterial strains were tested for purity by repeated streaking on sterile nutrient agar plates. The isolated colonies obtained were picked and streaked onto sterile nutrient agar slants, which were then incubated at $37^{\circ} \mathrm{C}$ for $24 \mathrm{~h}$. The bacterial cells were scraped off using sterile inoculation loops and mixed well for uniformity in HEPES buffer. The OD was measured at $600 \mathrm{~nm}$. OD was adjusted so that every $10 \mu \mathrm{l}$ of bacterial suspension contained approximately $10^{3}$ colony forming units.

\section{Determination of antimicrobial activity by well diffusion method} The susceptibilities to antimicrobials were determined by well diffusion technique [20]. Antibacterial activity was expressed in terms of radii of the zone of inhibition and was measured in mm using a scale. The antimicrobial activity of the hemolymph protein was studied using the above-mentioned bacteria which are designated as human pathogens. Streptomycin was used as a positive control for bacteria. In vitro antibacterial assay was carried out for ammonium sulfate precipitated protein of different saturation, dialyzed, and fast protein liquid chromatography (FPLC) protein fraction by well diffusion technique.

The agar plate surface is inoculated by spreading a volume of the microbial inoculum over the entire agar surface. Then, a hole with a diameter of 6-8 $\mathrm{mm}$ is punched aseptically with a sterile cork borer or a tip, and a volume $(20-100 \mu \mathrm{L})$ of the antimicrobial agent or extract solution at desired concentration is introduced into the well. $10 \mu \mathrm{g} / \mathrm{ml}$ positive control Streptomycin, negative controls (sterile distilled water) were also introduced into the well; then, agar plates are incubated under suitable conditions depending on the test microorganism. The antimicrobial agent diffuses in the agar medium and inhibits the growth of the microbial strain tested. After incubation at room temperature $\left(37^{\circ} \mathrm{C}\right)$ for $24 \mathrm{~h}$, antibacterial activity that expressed in terms of the diameter of the zone of inhibition was measured and recorded.

\section{Purification of protein using ion exchange chromatography}

The dialyzed sample of $5 \mathrm{ml}$ with a protein content $2 \mathrm{mg} / \mathrm{ml}$, was applied to an $8 \times 1 \mathrm{~cm}$ carboxymethyl sepharose cation-exchange column. The column was equilibrated with $50 \mathrm{mM}$ sodium phosphate ( $\mathrm{pH}$ 6.5). Unbound material was eluted by extensive washing with buffer at a flow rate of $1 \mathrm{ml} / \mathrm{min}$. Bound material was eluted with a two-step gradient of $50 \mathrm{mM}$ Sodium phosphate ( $\mathrm{pH} \mathrm{6.5)}$ with $0 \pm 50 \%$
$\mathrm{NaCl}$ over $30 \mathrm{~min}$ and $50 \pm 100 \% \mathrm{NaCl}$ over 15 min. Fractions (1 mL) were collected, and absorbances read at $280 \mathrm{~nm}$. Fractions from peaks showing antibacterial activity were pooled, filtered $(0.2 \mathrm{~mm})$, and subjected to further purification.

\section{FPLC}

Fractions with antibacterial activity after ion exchange chromatography were further purified by FPLC (FPLC, AKTA purifier, GE healthcare). The size exclusion column, Sephacryl TM S100 HR was used for the chromatography technique. The column was washed and equilibrated before the run with $0.1 \mathrm{M}$ phosphate buffered saline buffer (pH 6). All the purification parameters were programmed by the software UNICORN 5.31. The flow rate of buffer was set at $500 \mu$ per minute, and the column pressure was maintained below $0.15 \mathrm{MPa}$. $280 \mathrm{~nm}$ ultraviolet (UV) filter was used to read absorbance. Sample $(1.5 \mathrm{ml})$ which was earlier precipitated and desalted was injected into AKTA purifier system. The parameters such as UV, conductivity, flow rate, fractions, temperature, and pressure were continuously monitored. The fractions were collected automatically by Frac-920 which was earlier programmed to collect a fixed volume of $2 \mathrm{ml}$ per fraction. The peak fractions were collected, and the protein concentration was estimated. The selected fractions were analyzed by sulfate polyacrylamide gel electrophoresis (SDS-PAGE) or by silver staining method.

\section{Gel trypsin digestion}

Trypsin digestion was done according to the method described by Lazarev [21]. The FPLC fraction containing $102 \mu \mathrm{g} / \mathrm{ml}$ protein content was resolved in $12 \%$ SDS-PAGE and visualized by silver staining method. The protein bands were cut out of the gel and subjected to several processes includes reduction, alkylation, washing steps, and finally treated with trypsin followed by peptide extraction. The gel sliced was diced to small number of pieces and placed in a fresh Eppendorf tube. The gel pieces were immersed in the destaining solution for 10 min intervals (3-4 times) until the gel pieces become translucent white. The gels were dehydrated using acetonitrile and Speedvac till complete dryness. Using DTT, the gel pieces were rehydrated and kept for incubation for an hour. After incubation, the DTT solution was removed. The gel pieces were now incubated with Iodoacetamide for $45 \mathrm{~min}$. The supernatant was removed, and the gel was incubated with ammonium bicarbonate solution for 10 min. Trypsin solution was added and incubated overnight at $37^{\circ} \mathrm{C}$. The digest solution was transferred to fresh Eppendorf tubes. The gel pieces were extracted thrice with extraction buffer, and the supernatant was collected each time into the Eppendorf above and subjected to matrix-assisted laser desorption ionization-time-of-flight mass spectrometry (MALDITOF MS) analysis. Further analysis was done with FLEX ANALYSIS SOFTWARE for obtaining the PEPTIDE MASS FINGERPRINT.

\section{RESULTS AND DISCUSSION}

In the first isolation step, the hemolymph of $O$. senex senex was subjected to ion exchange chromatography. The hemolymph was fractionated into 30 fractions. A chromatogram obtained was shown in Fig. 1. Six peaks were observed. Antimicrobial activities were found to be concentrated on peaks $(1,2,3,4,5$, and 6$)$. Protein profile of active fractions was also done using SDS-PAGE.

Cation exchange of dialyzed extracts of the hemolymph on a carboxymethyl sepharose column produced an elution profile with two major peaks and four minor peaks. Antibacterial activity (measured by areas of clear zones in bacterial lawns) was detected against the Grampositive bacteria. High-resolution SDS/PAGE of fractions 16 revealed major bands at $40 \mathrm{kDa}$ and $33 \mathrm{kDa}$ as well as several bands of higher molecular mass on staining with Coomassie Blue.

The most active component (Fraction 16) was in the second fraction which displayed highest antimicrobial activity was pooled and was taken for FPLC. A total of 96 fractions were collected using 200 volume of sodium phosphate buffer ( $50 \mathrm{mM}, \mathrm{pH}$ 6.5) solution. The chromatogram (Fig. 1) shows that fraction 16 was firstseparated into three chromatographic peaks 
by Sephadex G-100 chromatography. Fraction 1 (Tube 94-98) showed a mild peak with very low molecular weight peptide and fraction 2 (48-51) showed a peak with low molecular weight, and fraction 3 (16-28) showed peak with high molecular weight proteins. Fractions 1 and 3 was not taken for further studies because fraction 1 contained undetectable protein level and fraction 3 has high molecular weight proteins (>100 KDa). Hence, fraction 2 (48-51) was pooled and applied into a high-resolution silver stained SDS/PAGE. To determine the molecular sizes of proteins eluted from the FPLC exchange column (fractions 48, 49, 50, and 51), a 15\% Tris/Tricine SDS PAGE polyacrylamide gel electrophoresis was conducted under reducing conditions [22]. The molecular masses of the proteins were determined using a protein ladder, and protein bands were visualized using silver staining. It revealed that fraction 49 and 50 showed number of protein bands ranges from $40 \mathrm{KDa}$ to $120 \mathrm{KDa}$, whereas fraction 51 showed a single band at 33KDa. The fraction 51 of $33 \mathrm{KDa}$ (represented in peak 2 ) showed the strongest activity against $P$. aeruginosa among all fractions attained. Gel electrophoresis of the FPLC fractions revealed single bands with a molecular weight of $33 \mathrm{KDa}$ in fractions 51 that were not seen in the other fractions (data not shown). This indicates the presence of protein $(>10 \mathrm{kDa})$ in FPLC fractions 51 but not in other FPLC fractions. Therefore, fraction 51 was loaded onto ultra-performance liquid chromatography with a linear ion trap-Orbitrap mass spectrometer for further purification and identification, aiming at revealing all peptide sequences in a simple and economical way.

\section{MALDI MS/MS analysis}

The sequence of the amino acids in peptides was proposed on the basis of the collision dissociation experiments and homology of known peptides supported by the fragmentation pattern. The electrospray ionization -MS result showed the presence of several molecular mass ranges of $\mathrm{m} / \mathrm{z} 200$ to 4500 .

The $33 \mathrm{KDa}$ protein of potent antibacterial activity against pathogenic bacteria was taken to MALDI-TOF/MS after digesting it with trypsin. From the spectral data (Fig. 2), 8 peaks were observed 868.591, 1334.962, 1638.923, 1832.030, 2094.128, 2501.294, 2705.248, and 2916.519. Three prominent peaks $1334.962,1638.923$, and 1832.030 were subjected to analysis. The peptide mass values, amino acid sequence, and composition for each peak were detected by the MASCOT search engine. A MALDI-TOF mass spectrum was used for the analysis of peptide mass fingerprinting and MS/MS ion search.

MALDI-TOF/MS/MS data of $33 \mathrm{KDa}$ protein were analyzed through the MASCOT search engine matching 8 peptides (Table 1). The molecular weight of these peptides ranged from 1600 Da to $2100 \mathrm{Da}$. The observed masses were all <2000 Da compared to their calculated masses which may be due to the loss of one water molecule.

Amino acid sequences, theoretical and estimated molecular masses, isoelectric point, hydrophobic ratio and stability of peptides isolated from the hemolymph of $O$. senex senex:

a. Net charge was calculated based on negatively charged amino acid (E and D) and positively charged amino acid (K, R, and $H$ ) in the peptide sequence;

b. Calculated the percentage of hydrophobic residues (I, V, L, F, C, M, A, and $\mathrm{W}$ ) in the peptide sequence [23].

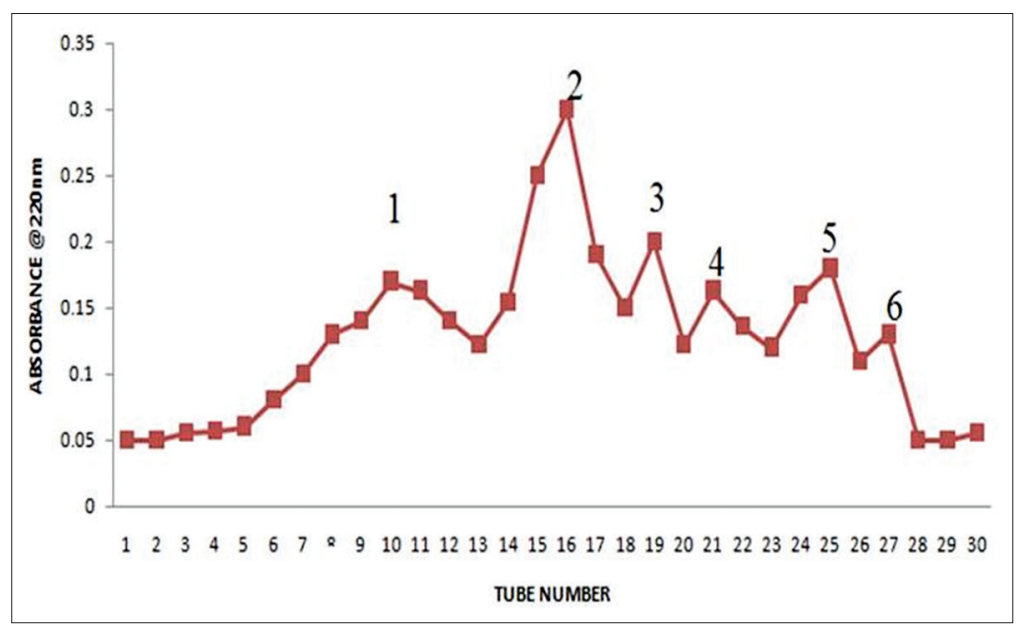

Fig. 1: Chromatogram of antimicrobial protein purified by ion exchange chromatography

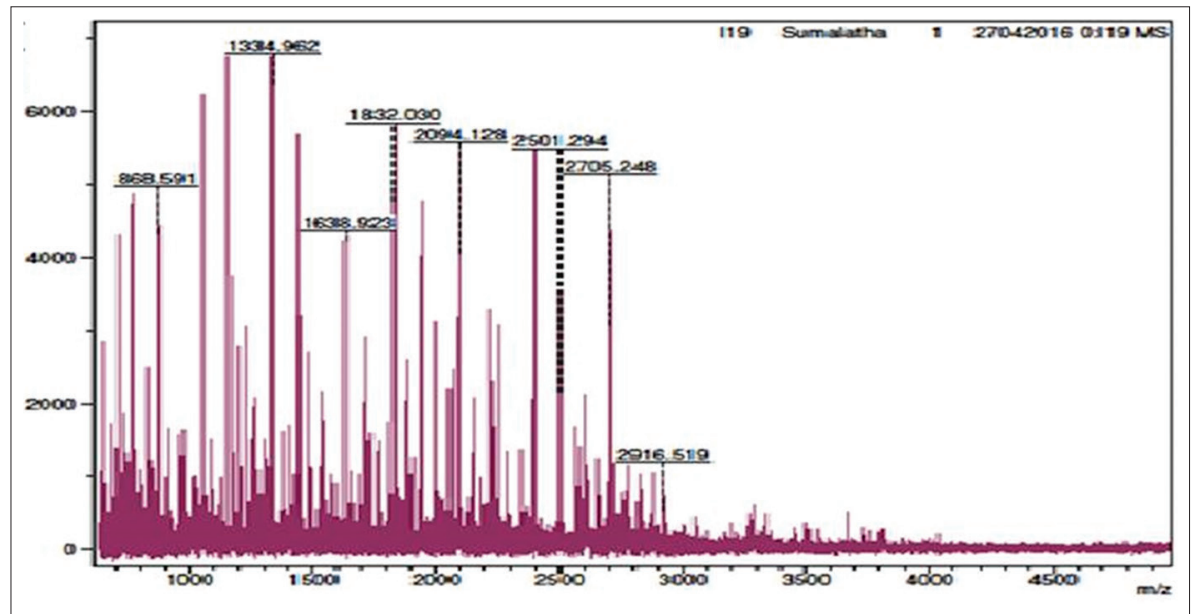

Fig. 2: Antimicrobial protein analysis using MALDI-TOF 
Eight peptides with charges were identified including five cationic peptides KGTYYPLTGMSKEVQQKL (CATIONIC I) RIRQVEVGVGSMNKG (CATIONIC II), RTTYMFPLLSESKR (CATIONIC III), RELTNYLMKILTERG (CATIONIC IV), and RLDLAGRDLTNYLMKI (CATIONIC V) and three anionic peptides RQCMEELLLMDEFDKY (ANIONIC I), RDLIDYLMKILTERG (ANIONIC II), and RLDLAGRDLTDYLMKI (ANIONIC III). Cationic peptides II, III, and IV possess the highest cationic charges $(+2)$ and its hydrophobic ratio is $<28 \%$, whereas Cationic IV and VII as hydrophobic ratio of $27 \%$ and $44 \%$ and lowest cationic charges $(+1)$. The antibacterial activity of cationic peptides can be modulated through modification of net charge or the ratio of hydrophobicity $[24,25]$. Nevertheless, the exposed basic residues of anionic peptides are not essential for their antibacterial activities. The study of freshwater crab's immune responses is not only limited by a lack of genomic data but also of a clear understanding of post-translational control. The complete study of identification, characterization, and function ascribing of the significance and biological functions of antimicrobial proteins have mainly been explored by genomic and homology-based technologies. However, the proteomics-based approach plays a very key role in knowing about novel proteins and to characterize the actual function of the proteins.

\section{Antimicrobial activity}

The antibacterial activity of crude and purified antimicrobial protein of $O$. senex senex was investigated against a range of six different strains (E. coli, P. aeruginosa, S. typhi, S. aureus, B. subtilis, and $V$. parahaemolyticus) (Table 2). The results demonstrated that the induced hemolymph showed strong activity against all the tested strains and showed the highest zone of inhibition against $S$. aureus $(28.32 \pm 0.402 \mathrm{~mm})$ followed by $V$. parahaemolyticus $(18 \pm 0.675 \mathrm{~mm})$, P. aeruginosa $(16.12 \pm 0.476 \mathrm{~mm})$, E. coli $(15 \pm 0.303 \mathrm{~mm})$, and S. typhi $(14.46 \pm 0.221 \mathrm{~mm})$ and minimum zone of inhibition was observed against $B$. subtilis $(12.75 \pm 0.576 \mathrm{~mm})$. Streptomycin was used as positive control and distilled water as a negative control.

This study has demonstrated antimicrobial activity in the hemolymph and consistently exhibited antimicrobial activity against 6 species of bacteria, including Gram-positive and Gram-negative species. The data indicate the intrinsic antimicrobial activity which plays a larger role in the defense against invading pathogens. Numerous studies have been reported in the hemolymph of marine crabs. LsStylicin-1, a novel negatively charged antimicrobial peptide, with
82 residues was identified from the penaeid shrimp, Litopenaeus stylirostris [26]. Antibacterial activity of hemolymph of freshwater crab Maydelliathelphusa against respiratory pathogens was also reported [27]. Furthermore, the hemolymph of Portunus segnis crabs also elucidated significant levels of antimicrobial activity [28]. In the present study, the presence of larger antibacterial molecules of $33 \mathrm{KDa}$ in hemolymph of 0 . senex senex possesses antibacterial activity against bacterial species. There are few reports with high molecular weight antibacterial protein with a size of 36-64 kDa from the serum of Scylla serrata [29], and $24.7 \mathrm{kDa}$ size antibacterial protein is isolated from $S$. serrata [30]. So far in decapod crustaceans, the antimicrobial peptides isolated from the hemolymph are in the range of $3.7-12 \mathrm{kD}[31,32]$.

Two clear bands with the molecular weight of $43 \mathrm{kDa}$ in female crab and $25 \mathrm{kDa}$ in male crab are isolated from Dromia dehaani [33]. The expression of proteins was detected in the gel of molecular weight between 25.6 and $75.8 \mathrm{KDa}$, which is similar to the antimicrobial peptides ( $56.8 \mathrm{kDa})$ isolated from the hemolymph of Thalamita crenata [34]. Similarly isolation and characterization of the antibacterial peptides from mud crab, S. serrata was done [34]. Further, an attempt was made to ascertain the active peptide present in the hemolymph of Rapana rapiformis through the SDS-PAGE and revealed that it possesses a protein with molecular mass of $35 \mathrm{kDa}$. Molecular weight ranging between 15 and $60 \mathrm{kDa}$ was found in the hemolymph of a shore crab, Ocypode macrocera [35].

Key features of AMPs are a high content of cysteine and glycine and the presence of disulfide bonds, which are important for intensifying structural stability under stress conditions [36]. Concerning AMPs, several physicochemical characteristics like hydrophobicity, the helical hydrophobic moment, as well as the size and the net charge of the peptide have been associated with the biological activity of them [37]. However, any of these characteristics were not solely sufficient to correlate with the antimicrobial activity of the AMPs. In this case, however, the larger peptides were the AMPs that manifested optimum biological performance. Nevertheless, a fine balance in terms of physicochemical properties may define a successful AMP, i.e., one with high antimicrobial activity, low cytotoxicity, and in vivo stability [38].

\section{CONCLUSIONS}

The antimicrobial protein isolated from the hemolymph of freshwater crab 0 . senex senex was purified by ion exchange chromatography and

Table 1: In silico analysis of antimicrobial protein

\begin{tabular}{|c|c|c|c|c|c|c|c|c|c|c|}
\hline S.No & Peptides & Sequences & $\begin{array}{l}\text { Number } \\
\text { of amino } \\
\text { acids }\end{array}$ & Cal/observed mass & $\begin{array}{l}\text { Net } \\
\text { charge }^{a}\end{array}$ & $\begin{array}{l}\text { Hydrophobic } \\
\text { ratio }^{b}\end{array}$ & Score & $\begin{array}{l}\text { Molecular } \\
\text { weight }\end{array}$ & pI & Stability \\
\hline 1 & CHH-CANPG & RCMEELLLMDEFDKY & 16 & $1831.7678 / 1832.0190$ & -3 & -0.637 & 6 & 2063.39 & 4.18 & Unstable \\
\hline 2 & KARG-PENMO & KGTYYPLTGMSKEVQQKL & 18 & $1828.9029 / 1832.0190$ & +2 & -1.300 & 0 & 2086.94 & 9.40 & Stable \\
\hline 3 & GELSOLIN & RIRQVEVGVGSMNKG & 15 & $1431.7504 / 1434.9350$ & +2 & -0.427 & 17 & 1629.90 & 10.84 & Stable \\
\hline 4 & PDH-ARMVU & RTTYMFPLLSESKR & 14 & $1431.6956 / 1434.9350$ & +2 & -0.714 & 6 & 1729.03 & 9.99 & Unstable \\
\hline 5 & ACT2-ARTSX & RDLIDYLMKILTERG & 15 & $1637.8698 / 1638.9031$ & 0 & -0.233 & 14 & 1836.18 & 6.12 & Stable \\
\hline 6 & ACT-CALFI & RELTNYLMKILTERG & 15 & $1638.8651 / 1638.9031$ & +1 & -0.580 & 13 & 1837.17 & 8.59 & Stable \\
\hline 7 & ACT-PROCL & RLDLAGRDLTNYLMKI & 16 & $1637.8447 / 1638.9031$ & +1 & -0.150 & 12 & 1892.25 & 8.59 & Stable \\
\hline 8 & ACT1-ARTSX & RLDLAGRDLTDYLMKI & 16 & $1638.8287 / 1638.9031$ & 0 & -0.150 & 11 & 1893.23 & 6.04 & Stable \\
\hline
\end{tabular}

Table 2: Antimicrobial activity of an antimicrobial protein from the hemolymph of 0 . senex senex against human pathogens

\begin{tabular}{llllll}
\hline S.No & Organism & Streptomycin positive control $(\mathbf{m m})$ & Negative control & Crude sample (mm) & Antimicrobial protein (mm) \\
\hline 1 & E. coli & $20.14 \pm 0.048$ & - & $25.15 \pm 0.461$ & $14.94 \pm 0.303$ \\
2 & P. aeruginosa & $20.34 \pm 0.702$ & - & $31.42 \pm 0.383$ & $16.12 \pm 0.476$ \\
3 & S. typhi & $15.24 \pm 0.378$ & - & $26.1 \pm 0.187$ & $14.46 \pm 0.221$ \\
4 & S. aureus & $20.72 \pm 0.816$ & - & $36 \pm 0.645$ & $28.32 \pm 0.402$ \\
5 & B. subtilis & $18.4 \pm 0.353$ & - & $19.9 \pm 0.1$ & $12.75 \pm 0.576$ \\
6 & V. parahaemolyticus & $17.08 \pm 0.653$ & - & $24.84 \pm 0.114$ & $17.96 \pm 0.675$ \\
\hline
\end{tabular}

Values are expressed as mean \pm SEM of 5 samples and expressed in millimeters (mm). SEM: Standard error of mean, E. coli: Escherichia coli, P. aeruginosa: Pseudomonas aeruginosa, S. typhi: Salmonella typhi, S. aureus: Staphylococcus aureus, B. subtilis: Bacillus subtilis, V. parahaemolyticus: Vibrio parahaemolyticus,

O. senex senex: Oziotelphusa senex senex 
fast protein chromatography and the molecular weight of the protein was analyzed using MALDI-TOF. In silico analysis of the protein was done using MASCOT search engine, showed the presence of 8 peptides. The antimicrobial protein exhibited antibacterial activity against Grampositive and Gram-negative bacteria.

\section{ACKNOWLEDGMENT}

Authors thank the authorities of Guru Nanak College and G.S. Gill Research Institute, Chennai, Tamil Nadu, India, for their encouragement and facilities provided for the research work

\section{CONFLICTS OF INTEREST}

The authors report no conflicts of interest .

\section{REFERENCES}

1. Rosa RD, Barracco MA. Antimicrobial peptides in crustaceans. Invert Surviv J 2010;7:262-84

2. Yeo DC, Ng PK, Cumberlidge N, Magalhes C, Daniels SR, Campos MR. Global diversity of crabs (Crustacea: Decapoda: Brachyura) in freshwater. Hydrobiologia 2008;595:275-86.

3. Rameshkumar G, Ravichandran S, Kaliyavarathan G, Ajithkumar TT. Antimicrobial peptide from the crab, Thalamita crenata (Latreille, 1829). World J Fish Mar Sci 2009a; 1:74-9.

4. Ravichandran S, Jeyalakshmi S, Sudha S, Anbuchezhian R. Antimicrobial peptides from the haemolymph of the prawn, Macrobrachium rosenbergii. Bangladesh J Pharmacol 2010;5:62-7.

5. Bordenave S, Fruitier I, Ballandier I, Sannier F, Gildberg A, Batista I, et al. HPLC preparation of fish waste hydrolysate fractions. Effect on guinea pig ileum and ACE activity. Prep Biochem Biotechnol 2002;32:65-77.

6. Picot L, Bordenave S, Didelot S, Fruitierarnaudin I, Sannier F, Thorkelsson G, et al. Antiproliferative activity of fish protein hydrolysates on human breast cancer cell lines. Process 2006;41:1217- 22.

7. Liu Z, Liu H, Liu X, Wu X. Purification and cloning of a novel antimicrobial peptide from salivary glands of the hard tick, ixodes sinensis. Comp Biochem Physiol B Biochem Mol Biol 2008;149:557- 61 .

8. Devakumar D, Kumaran T, Jayanthi J, Ragunathan MG. Efficiency of Psidium guajava leaf extract on the nitrogenous wastes in Aeromonas hydrophila infected fresh water crab, Oziotelphusa senex senex. J Recent Trends Biosci 2012;2:47-52.

9. Dong Y, Jing T, Meng Q, Liu C, Hu S, Ma Y, et al. Studies on the antidiabetic activities of cordyceps militaris extract in dietstreptozotocin-induced diabetic sprague-dawley rats. Biomed Res Int 2014;2014:160980.

10. Sujeetha M, Sharmila S, Jayanthi J, Ragunathan MG. Antioxidant property of some extracts derived from the mud crab, Scylla serrata. Int J Phytopharmacol 2015;6:111-3.

11. Swetha CH, Girish BP, Reddy PS. Reproductive cycle and fecundity in natural population of edible freshwater crab, Oziothelphusa senex senex (Fabricius, 1798) (Decapoda: Brachyura). J Aquac Res Dev $2015 ; 6: 349$

12. Krishnamoorthy RV, Srihari K. Changes in excretory pattern of the freshwater field crab, Paratelphusa hydrodromous upon adaptation to higher salinities. Mar Biol 1973;21:341-8.

13. Reddy PS. Neuroendocrine control of metabolism in the freshwater crab Oziotelphusa senex senex. J Crustacean Bio 1990;10:595-607.

14. Reddy PS. Molt inhibition in the crab Oziotelphusa senex senex in response to heavy metal toxicity. Pollut Res 1992;11:191-5.

15. Söderhäll K, Cerenius L. Role of the prophenoloxidase-activating system in invertebrate immunity. Curr Opin Immunol 1998;10:23-8

16. Bhavan S, Saravana S, Radhakrishnan S, Shanthi R, Poongodi R. Proximate composition and profiles of amino acids and fatty acids in the muscle of adult males and females of commercially viable prawn species Macrobrachium rosenbergii collected from natural culture environments. Int J Biol 2010;2:107-19.
17. Soundarapandian P, Ananthan G. Effect of unilateral eyestalk ablation and diets on the biochemical composition of commercially important juveniles of Macrobrachium malcomsonii (H. Milne Edwards). Int J Zool Res 2008;4:106-12.

18. Ng PK, Guinot D, Davie PJ. Systema brachyurorum: Part I. An annotated checklist of extant brachyuran crabs of the world. Raffles Bull Zool 2008;17 Suppl:1-286.

19. Söderhäll K, Smith VJ. Separation of the haemocyte populations of Carcinus maenas and other marine decapods, and prophenol oxidase distribution. Dev Comp Immunol 1983;7:229-39.

20. Chavan PA. Evaluation of Antimicrobial activity of various medicinal plants extracts of Latur zone against pathogens. Int J Life Sci Sci Res 2016;2:612-8

21. Lazarev AV, Rejtar T, Dai S, Karger BL. Centrifugal methods and devices for rapid in-gel digestion of proteins. Electrophoresis 2009;30:966-73.

22. Schägger $H$, von Jagow $G$. Tricine-sodium dodecyl sulfatepolyacrylamide gel electrophoresis for the separation of proteins in the range from 1 to $100 \mathrm{kDa}$. Anal Biochem 1987;166:368-79.

23. Song R, Wei RB, Luo HY, Wang DF. Isolation and characterization of an antibacterial peptide fraction from the pepsin hydrolysate of half-fin anchovy (Setipinna taty). Molecules 2012;17:2980-91.

24. Kustanovich I, Shalev DE, Mikhlin M, Gaidukov L, Mor A. Structural requirements for potent versus selective cytotoxicity for antimicrobial dermaseptin S4 derivatives. J Biol Chem 2002;277:16941-51.

25. Zelezetsky I, Pag U, Sahl HG, Tossi A. Tuning the biological properties of amphipathic alpha-helical antimicrobial peptides: Rational use of minimal amino acid substitutions. Peptides 2005;26:2368-76.

26. Rollanda JL, Abdelouahabb M, Dupontc J, Lefevrec F, Bachèrea E, Romestanda B. Stylicins, a new family of antimicrobial peptides from the pacific blue shrimp, Litopenaeus stylirostris. Mol Immunol 2010;47:1269-77.

27. Singh S, Arya P, Bahuguna S, Mehta JP, Bhat G, Chowdhary AK, et al. Antibacterial activity from haemolymph of freshwater crab of genus maydelliathelphusa against respiratory tract pathogens. Int J Pharm Pharm Sci 2016;8:324-5.

28. Hajirasouli M, Pazooki J. Antimicrobial potential of hemolymph and hepatopancreas of portunussegnis crabs. Int J Pharm Pharm Sci 2014;6:601-3.

29. Hoq MI, Seraj MU, Chowdhury S. Isolation and characterization of antibacterial peptides from the mud crab, Scylla serrata. Pak J Biol Sci 2003;6:1345-53.

30. Makesh SV. Studies on Antibacterial Factors in the Hemolymph of the Marine Crab, Scylla serrata Forskal (Crustacea: Decapoda) Ph. D. Thesis, University of Madras; 2006.

31. Herbinière J, Braquart-Varnier C, Greve P, Strub JM, Frere J, Van Dorsselaer A. 2 Armadillidin: A novel glycine-rich antibacterial peptide directed against gram-positive bacteria in the woodlouse Armadillidium vulgare (Terrestrial Isopod, Crustacean). Dev Comp Immunol 2005;29:489-99.

32. Battison AL, Summerfield R, Patrzykat A. Isolation and characterization of two antimicrobial peptides from hemocytes of the American lobster Homarus americanus. Fish Shellfish Immunol 2008;25:181-7.

33. Fredrick WS, Ravichandran S. Hemolymph proteins in marine crustaceans. Asian Pac J Trop Biomed 2012;2:496-502.

34. Rameshkumar G, Ravichandran S, Arvaindhan T. Antimicrobial proteins from the crab, Charybdis lucifera (Fabricus, 1798). MidEast J Sci Res 2009b;4:40-3.

35. Sivaperumal P, Kamala K, Natarajan E, Dilipan E. Antimicrobial peptide from crab haemolypmh of Ocypoda macrocera (Milne Edwards 1852) with reference to antioxidant: A case study. Int J Pharm Pharm Sci 2013;5:719-27

36. Manisha T, Anjali B, Ajeet S. Isolation of antibacterial protein/peptide from ficus glomerata leaf. Int J Curr Pharm Res 2016;8:24-7.

37. Yin LM, Edwards MA, Li J, Yip CM, Deber CM. Roles of hydrophobicity and charge distribution of cationic antimicrobial peptides in peptidemembrane interactions. J Biol Chem 2012;287:7738-45.

38. Arenas I, Villegas E, Walls O, Barrios H, Rodríguez R, Corzo G, et al. Antimicrobial activity and stability of short and long based arachnid synthetic peptides in the presence of commercial antibiotics. Molecules 2016;21:pii: E225. 